\section{NARRACIONES ESPAÑOLAS DEL FIN DEL MUNDO. II. LAS NOVELAS RELIGIOSAS}

\author{
Agustín Jaureguízar \\ Doctor Ingeniero de Caminos
}

Periodista

\begin{abstract}
There are three novels published between 1920 and 1935 which I have chosen as a token of spanish classical narrative. Their authors judge a fading Mankind on its evilness, reaching different outcomes: in one, the righteous are saved while the sinners are banished to Hell, at so great a speed that they are still alive on arrival; in another, only a handful of the chosen, who get to another planet, survives, and in the last, well, Mankind is extinguished and God creates a new Man and a new Woman in a Paradise where He's uprooted the tempting Tree of Knowledge.
\end{abstract}

KEY WORDS: Canon Valverde; Carlos Ortí Muñoz; Bernardo Morales San Martin; End of the World (religious); The Beast (Apocalypse); Elijah vs the Antichrist; End of Days; Signs of Apocalypse; Man's Twilight; Creation of a new Mankind.

Decía en el artículo anterior, dedicado a las novelas laicas, que hubieron de transcurrir muchos siglos antes de que esta literatura pasara del ámbito de lo sagrado al de lo profano. Aparece recogida desde la Antigüedad en los libros santos de las diversas religiones $y_{1}$ sin recurrir al Apocalipsis cristiano, del que hablaré más adelante con largueza, el Siddhanta, por poner un ejemplo menos conocido, el libro de las escrituras jinistas, nos sitúa en el quinto período de un ciclo descendente en que las condiciones físicas y morales irán empeorando paulatinamente hasta que, a su final, dentro de veinte mil años, durante cuarenta y nueve días lloverá del cielo una materia corrosiva que acabará con la vida sobre la Tierra. Y cabría poner otros varios ejemplos.

Mucho después algunos narradores escribieron novelas del advenimiento del fin de los tiempos, entre las que no faltaron las de motivación religiosa extrema, feroces novelas de escarmiento escritas con el propósito de llamar a la conversión a sus lectores, que fueron con frecuencia verdadera literatura de combate. Ejemplo destacado en

\section{SPANISH STORIES ON THE END OF THE WORLD. II. THE RELIGIOUS NOVELS}

RESUMEN: Como muestra de las narraciones clásicas españolas del fin de los tiempos se han escogido tres novelas publicadas entre 1920 y 1935 . Sus autores juzgan por su maldad a una Humanidad que desaparece, llegando a resultados distintos: en una los justos se salvan mientras los pecadores son arrojados a los infiernos a tan gran velocidad que llegan vivos a ellos; en otra sólo sobrevive un puñado de elegidos, que alcanza otro planeta, y en la tercera, en fin, la Humanidad se extingue por completo y Dios crea otro Hombre y otra Mujer en un Paraíso del que ha arrancado de raíz el árbol tentador del Bien y del Mal.

PALABRAS CLAVE: Canónigo Valverde; Carlos Ortí Muñoz; Bernardo Morales San Martín; El fin religioso del mundo; La Bestia del Apocalipsis; Elías vs Anticristo; El fin de los tiempos; Las señales del Apocalipsis; El ocaso del hombre; Creación de otra Humanidad.

España es La Bestia del Apocalipsis', del canónigo Valverde, cuyo prologuista escribe:

Se adelanta varios siglos y describe la comunicación que puede haber entre nuestro mundo y otros mundos posibles. Julio Verne llegó a eso, pero con recursos de distinta índole y sin sospechar que luego hubiera quien matizara con tanta originalidad las relaciones interplanetarias que él vaticinó.

Y en una Advertencia Preliminar el autor escribe a su vez:

Benévolo lector: Los sucesos que te cuento en este libro comprenden casi toda la vida humana, desde los tiempos patriarcales hasta el fin del mundo. Algo refiero también de los selenitas y marcianos por la influencia que han tenido y tendrán sobre nuestro planeta estos habitantes extraterráqueos.

La sensación de que va uno a encontrarse con una novela cientificticia en el más puro sentido de la palabra, dentro 
de la gran elasticidad semántica del término, se refuerza al leer en el principio del libro que en el hemisferio oculto de la luna existen dos estados separados por un mar de lava y divididos por su religión, ya que en el uno se practica una semejante a la hebrea primitiva y en el otro se rinde culto a la naturaleza corpórea. Se celebra en éste la fiestaconcurso de la Consagración de la Reina, en la que una princesa virgen remonta el vuelo con las alas áulicas para que la siga una corte de jóvenes voluntarios, provistos de unas más modestas alas de tafetán que ellos mismos han confeccionado. Quien logre fecundar a la princesa en las alturas -sigo la terminología del autor- se convertirá en su esposo y ambos serán los futuros reyes.

Y en aquel momento abrióse la flor del cáliz y apareció desnuda, deslumbrante de gracia ante los ojos absortos de la muchedumbre, la más bella hija del planeta: Zeos Lorimera.

Remonta el vuelo y pronto empiezan a caer rendidos los primeros pretendientes, que pagan con la vida la osadía de su empeño, pues, en cuanto caen exhaustos al suelo, son cubiertos de pez y conducidos a unas piras preparadas al efecto para ser quemados en ellas. Sólo uno de los jóvenes, de sangre real, logra alcanzar a Zeos y tomarla en sus brazos, favorecido de disponer de una pila eléctrica para ayudarse: ya la ha visto antes desnuda, cuando la sorprendió nadando en la piscina del palacio real, y desde entonces no piensa sino en conseguirla.

Su padre, que es un hombre poderoso y práctico, le ha dicho al alquimista doméstico:

Tú, hijo de las tinieblas, que te has pasado lo mejor de la vida oyendo el estridor de las cadenas en las mazmorras del Imperio, elige entre esa muerte perpetua o la vida y la libertad, con mil esclavos que en todo te sirvan y mil esclavas que en todo te complazcan, y todo el oro de las minas de Oriente, si...

El hijo de las tinieblas no lo duda ni por un instante y aplica al hijo de su señor, que va también desnudo, una minúscula pila eléctrica bajo las alas, lo que le permite moverlas sin más esfuerzo de los brazos que el necesario para marcar la dirección.

Y hubiera alcanzado su objetivo si no fuera porque, desde el otro lado de la frontera, contempla la escena el príncipe heredero del estado vecino, que ha llegado hasta alli persiguiendo a un tigre $y$, entre escandalizado y encandilado por la más bella hija del planeta, dispara con su arco una flecha eléctrica que hace perder la pila al joven.

Elias, que así se llama el príncipe, regresa de inmediato a su palacio con el firme propósito de visitar a sus vecinos y exhortarlos a que cambien de costumbres, pero sus libros sagrados le prohiben cruzar el mar de lava que los sepa$\mathrm{ra}$, por lo que ordena a sus ingenieros que le construyan una nave con que dar la vuelta a la luna, dotándola de los necesarios sistemas de refrigeración que exigen las altas temperaturas del otro hemisferio y demás detalles técnicos.

Y dejando al príncipe ocupado en sobrevolar con su nave la cara visible de la luna, paso yo a ocuparme del autor, el presbitero accitano Juan José Valverde, hijo de Torcuato Valverde y Filomena Gómez, nacido en Guadix (Granada) el 3 de mayo de 1883 , según los datos que me ha facilitado amablemente su sobrino Joaquín.

En 1894 ingresó en el seminario de Guadix, ordenándose sacerdote en 1907 y licenciándose en teología en 1909. Fue profesor de latín, humanidades e historia en el seminario y en 1914 pasó a una parroquia de Baza, donde escribió sus primeros libros y entró en contacto con personalidades literarias como Rodríguez Marín, Ricardo León y Antonio Maura, más conocido éste como político, aunque también fue escritor de mérito.

Poco antes de dejar Baza, tras diez años de estancia en ella, el Ayuntamiento lo honró como hijo adoptivo de la ciudad y el Patrimonio Real lo nombró capellán y predicador de Sus Majestades. Regresó luego a su amada Guadix natal, la vieja Acid, -"la punta de lanza de Castilla clavada en Andalucia", que dijo Unamuno-, primero como párroco y después como canónigo de su catedral. Falleció el 1 de febrero de 1960 en Almería, aunque sus familiares lo trasladaron de inmediato a Guadix.

Ganó certámenes y premios literarios y escribió artículos periodísticos y varios libros. La Bestia del Apocalipsis aparece firmado en Guadix en 1931 e impreso y prologado en Andújar en 1935, lo que se explica porque el prologuista, su amigo de toda la vida Francisco Arias Abad, era el dueño de la editorial. 
Debo mi formación literaria a los clásicos latinos y de la teología saqué el alimento espiritual de mis libros [...] Preferi la novela porque en ella está todo lo que constituye la vida.

Su sobrino reproduce estas palabras suyas:

Ya en Baza revoloteaba en mi imaginación una obra, mitad fantástica, mitad profética, que apoyaré en los últimos descubrimientos de la ciencia y en las páginas del Libro de los Reyes y del Apocalipsis. La titularé El profeta Elías en Marte.

Volviendo a la novela, publicada finalmente con el título de La Bestia del Apocalipsis, cuando nuestro príncipe toma tierra en lo alto de una montaña, se le aparece Dios al más puro estilo bíblico -Elías significa Mi Dios es Yahweh-y le dice que abandone su noble propósito y se dirija a la Tierra a predicar a los israelitas el arrepentimiento y la conversión, si no quieren recibir un terrible castigo.

Hay un pueblo, Israel, a quien Yo he colmado de gracia, pero se han hecho sacrílegos y blasfemos, han pasado a cuchillo a los profetas y han levantado ídolos a Baal. Quiero que vayas alli para anunciar mis juicios y el terrible azote con que voy a castigar al pueblo.

A pesar de la amenaza de ser pasado a cuchillo como prende el camino de la Tierra, donde será el profeta Elías, al que la Escritura da por tesbita, de Tisbé de Galaad, adónde le encamina el ángel del Señor para hacerlo aterrizar en su supuesto lugar de origen. La novela pierde entonces buena parte de su fantasía y se va convirtiendo en un discurso religioso de distinto interés: Valverde reproduce ad pedem litteram cuanto narra el Libro de los Reyes, limitándose a rellenar los huecos véterotestamentarios para sus propósitos.

Cuando la Biblia dice que el rey Ajab (874-852 a.C.) dio culto a Baal, le erigió una estatua en el templo de Samaría e irritó a Dios aún más que los reyes que le habian precedido, Valverde lo atribuye a su esposa, la bella y famosa princesa fenicia Jezabel, que se habría casado con él por consejo de su thérafin. Este thérafin, instalado en la cámara de los dioses tutelares de las familias cananeas, era la quienes le precedieron, el príncipe mutado en profeta em- cabeza disecada del primogénito sacrificado a Baal, admirablemente conservada por procedimientos perdidos, que tenía bajo la lengua una lámina de oro con la inscripción de un espíritu inmundo. El suyo le dice a Jezabel -empleo la ortografía moderna-:

El reino de los hebreos está dividido entre Asá y Ajab. Éste, que es un espíritu inquieto, turbulento y rebelde, busca la ocasión de levantar altares en Israel, para que sus súbditos no tengan que ir todos los años a Judá, donde reina Asa, a ofrecer sacrificios en aquel templo, como manda la ley de Moisés. Tú eres hermosa como el sol y corre por tus venas la noble sangre de cien reyes. Cásate con Ajab, levanta templos a Baal, sacrifica a todos los profetas y borra el nombre de Yahweh de todas las tribus.

Así lo hace y la cólera de Dios termina por castigar duramente a la casa de Israel. Cumplida su misión, Elías sube al cielo en "un carro de fuego con caballos de fuego" en la Biblia, que en la ficción va a ser su nave espacial.

Tras este bloque episódico, se abre otro, unos nueve siglos más tarde en el planeta Marte. Si los selenitas eran en todo iguales a los terráqueos, los marcianos se les asemejan en su estatura y sus órganos vitales, aunque su piel es de color gris y su cara triangular. Su ciencia supera a la terrestre de entonces y están organizados en un solo estado, la República de Marte -supone el autor que este planeta es siete veces más pequeño que la Tierra-, de la que es Presidente el malvado y perverso Doctor Delevi, un monstruo de iniquidad que, cuando era secretario del candidato que iba a ganar las elecciones, lo apuñaló y lo arrojó al mar, sustituyéndolo en las listas y resultando elegido.

Delevi soñaba ser adorado como Dios en el corazón y en la conciencia de todo aquel pueblo materialista; sabía tanto como el diablo porque era el diablo su asesor y el resorte de todas sus acciones.

Se nos presenta en su despacho, donde conoce de un escultor un secreto que le interesa $y$, al despedirlo con la promesa de una recompensa, el premio que le otorga es pulsar un botón que abre una trampilla en el suelo y lo precipita a los hornos crematorios que están permanentemente encendidos en el sótano presidencial. El autor se complace en ocasiones con imágenes del Averno.

ARBOR Vol. 187749 mayo-junio [2011] 627-638 ISSN: 0210-1963

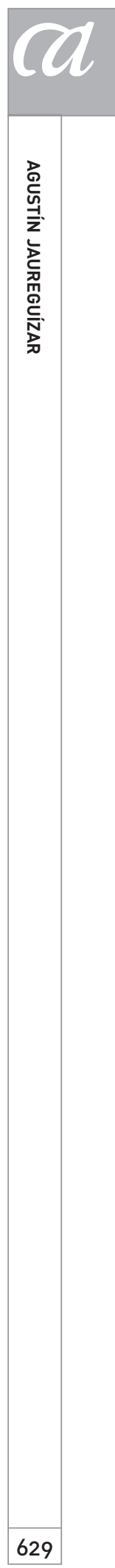

doi: 10.3989/arbor.2011.749n3014 
El pueblo, efectivamente, se ha ido volviendo materialista:

Lo había invadido todo el racionalismo del Estado. Los templos eran visitados más bien como museos que como casas de oración. Los sacerdotes, influenciados por el espíritu de los tiempos, sin fe ni conciencia, hacian de mala gana los oficios religiosos [...] y si se hacian ministros del Altísimo era porque en ello encontraban una manera como otra cualquiera de ganarse la vida.

Delevi atraviesa un momento de debilidad cuando se enamora de Leticia, la hija de quince años del Sumo Sacerdote, a la que por otra parte ha raptado de un modo miserable, y llega a plantearse el abandono de sus planes para compartir su vida con otra alma, con un verdadero amor. Mas se le aparece entonces el diablo que lo tienta primero con mujeres, luego con riquezas $y$, finalmente, mostrándole la hermosura de la gran Tierra, con sus nunca vistos bosques y selvas, mares y ríos, nubes y cielo, que le entregará "si postrado, me adorares". A diferencia de Cristo, a tanto no puede resistirse Delevi y cae de rodillas y lo adora, convirtiendo a Leticia en estatua de mármol, según el secreto que le confiara el escultor.

Poco después se celebra un magno Congreso de la Ciencia en el que el Presidente anuncia que los últimos descubrimientos permitirán la prolongación sin límites de la vida, en base al injerto y animación de las glándulas, pasando de inmediato a lanzar un ataque contundente contra la religión:

Y al caer en el olvido y el desprecio esa religión que ceñia nuestra garganta como dogal de hierro, podemos proclamar como ciudadanos conscientes, apoyados en las observaciones de la ciencia y en el testimonio de nuestra propia razón, que la existencia de los espíritus es una mentira y que Dios no existe.

El pueblo, en actitud comprensible, prefiere esa vida sin muerte que se le presenta al alcance de la mano a la futura post mortem que le predican sin demasiada convicción los sacerdotes, y está dispuesto a abandonar la fe.

¡Y, sin embargo, Dios existe! -dijo una voz poderosa, como voz de trompeta...
Es otra vez el profeta Elías, que responde a la petición de una señal que se le reclama para creer, exclamando en la línea de sus anteriores amenazas a Israel:

Generación adúltera y perversa, no merecéis señal alguna, pero como Dios tiene compasión de vosotros, os daré un signo: No veréis la luz del sol durante veinte horas, caerá fuego del cielo que destruirá el palatino y un terremoto diezmará los pueblos [...] Y en aquel momento se apagó el sol, se convirtió el palatino en una inmensa hoguera y un terrible movimiento sísmico echó por tierra, con innumerables edificios y monumentos, aquel soberbio palacio de la ciencia, bajo cuyos escombros quedaron sepultados todos los senadores y altos dignatarios.

Sólo se salvó Delevi, que en cuanto oyó las primeras palabras de Elías, corrió veloz a un aeroplano con el que alcanzó las tierras árticas y aterrizó en una pequeña isla deshabitada. Alli existía bajo el hielo una caverna en la que se hizo sepultar tras ser inyectado en sus músculos y en sus venas con una sustancia bituminosa con la que igualmente le recubrieron el cuerpo, que lo mantendría indefinidamente con la vida suspendida.

Pasan así otros veinte siglos, hasta que el diablo envía un águila negra a liberarlo de su envoltura y a extraer con el pico la sustancia que le había sido inyectada. En el viejo castillo de la isla, reconstruido por arte de encantamiento por el Maligno, utiliza por dias y más días otra invención marciana, el cronodiorama, que recoge imágenes del pasado $^{2}$.

Ve cómo el profeta Elías -que ya adelantaba el cristianismo en las palabras evangélicas que pronunció- ha convertido a esa religión a todo el pueblo de Marte, que la practica con fervor. Sumamente irritado, mueve los diales hacia la Tierra y se complace largamente en contemplar los momentos más crueles para el cristianismo, como la crucifixión y las persecuciones romanas. Luego Mahoma, Lutero y Voltaire dan ocasión al buen cura para exponernos sus errores, hasta llegar al triunfo del racionalismo con la Revolución Francesa. Alcanza después Delevi la guerra europea:

... y su espíritu miserable se complace viendo llorar a tantas madres sobre los mudos hogares, sobre la ruina de la patria querida... 
A continuación, en un futuro que parece próximo al del autor, el comunismo impone su dominio en el mundo:

La tea revolucionaria arde sobre el altar y sobre el trono,

Llegado a este punto, el doctor implora al príncipe de las tinieblas que lo transporte a la Tierra y en ella se desarroIlan los sucesos finales de la novela, cada vez de intención más profética: a Valverde le preocupan los tiempos que corren y una amenaza que cree real.

Mientras el Papa Pedro II y unos pocos fieles se esconden en las catacumbas, la Gran República de los Soviets, nueva Babilonia aún más depravada y envilecida, celebra una reunión de los presidentes de sus repúblicas en la Capilla Sixtina, al objeto de planear sus próximas acciones. Para su sorpresa, de pronto el mar Tirreno se alza mágicamente sobre su nivel y su ola más alta e hirviente se abre para dar paso a escuadrones de caballería que descienden ingrávidos hacia Roma, carros de asalto y formidables máquinas de combate científico-satánicas, carrozas de oro tiradas por elefantes y repletas de odaliscas $y$, finalmente, sostenido en el aire por el aliento de un dragón bicéfalo, el indescriptible trono de Delevi, con manto de armiño sobre sus hombros, cetro en sus manos y la triple corona imperial en su cabeza.

Cuando la soldadesca soviética -embriagada por el vino de las bodegas pontificias y enardecida por la visión de las odaliscas, que quieren para sí- pretende hacerles frente, un solo hombre dispara su arma y todo cuanto cae dentro del cono de luz de sus rayos queda reducido a cenizas. Ante tamaña exhibición, todos aceptan la nueva jefatura y pronto ondean sobre la cúpula de San Pedro, primero, y sobre toda la Ciudad Eterna y todo el mundo, después, los estandartes con la imagen y el número de la Bestia ${ }^{3}$.

La religión, que ya era perseguida, lo es ahora con más saña y hasta un cardenal resentido exhorta a los cristianos a que adoren al nuevo dios, al que ofrece en sus misas negras la sangre de las vírgenes cazadas en las catacumbas. Delevi obra prodigios con su poder satánico, hace caer fuego del cielo sobre los que no le adoran, reparte imágenes de la Bestia que gesticulan y hablan y hasta simula su muerte para convencer a los últimos incrédulos con su resurrección.

El cristianismo está a punto de ser borrado de la faz de la Tierra cuando aparece de nuevo Elías, esta vez acompañado de Enoch, el padre de Matusalén, que fue el otro personaje bíblico que ascendió al cielo sin conocer la muerte. El uno por Oriente y el otro por Occidente, levantan un formidable ejército de cristianos y judíos que han convergido en una misma fe. Se encuentran ante Roma y Enoch, que viene directamente del cielo, saluda a Elías con la buena nueva de que Zeos Lorimera ha encontrado gracia ante Dios.

Los secuaces de Delevi les dan muerte, pero ambos resucitan a la vista de todo el pueblo ${ }^{4}$. La batalla final tiene lugar en Armagedón, donde las tropas satánicas y las de quienes son ya los "reyes" soviéticos se enfrentan al ejército de los fieles.

El doctor lanzó una horrorosa y espeluznante blasfemia. Tembló la Tierra, negándose a sostener al hombre, vomitando fuego por la boca de cien volcanes. El sol, en medio del cenit, apagó totalmente su lumbre y las tinieblas se enseñorearon de los espacios.

-¡Adelante los míos! ¡Hartaos de sangre, pisotead en las tinieblas los cráneos de los imbéciles! ¡Viva Lucifer!

Los carros de asalto, las poderosas máquinas de guerra que manejaban las huestes infernales, las granadas mortiferas, la lengua de fuego de los cañones, el tableteo constante de las ametralladoras, el vivo fulgor de los cohetes, el crujir de los aceros, el choque de las masas mongólicas contra los espolones electrizados de las torres blindadas, lanzando fuego líquido, materias deletéreas y gases venenosos...

Mas la batalla no la resuelve toda esta parafernalia, sino la aparición de Cristo, que viene a juzgar a vivos y muertos, perdonando a los más y precipitando con tal rapidez al abismo a Delevi y a quienes llevan la imagen de la Bestia, que llegan vivos a los infiernos.

Escribió Asenjo Sedano que Valverde "estaba fabulosamente dotado para moverse en el mundo del barroco", y hace otro comentario certero cuando matiza que "no era el mundo de Verne el que más le seducía, sino el otro más avanzado de Wells", como corresponde a su propósito de interpretación de los hechos, por fantástica que ésta resulte.

Recurro a Saiz Cidoncha porque se ha aproximado a esta novela desde nuestra óptica, calificándola, junto con alguna más de su laya ${ }^{5}$, de epopeyas bárbaras, obras apocalípticas que son el reflejo en ciencia ficción de las posturas extremadas -en Valverde de derechas, en otros de iz-

ARBOR Vol. 187749 mayo-junio [2011] 627-638 ISSN: 0210-1963

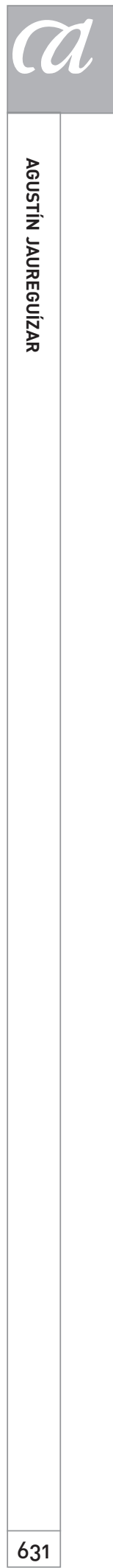


quierdas- que imperaban en la España de los años treinta del siglo XX. Esta vestimenta cientificticia no basta para ocultar la ideología de sus autores, de modo que las obras fueron ensalzadas por los unos y denostadas por los otros desde posiciones tomadas de antemano, al margen de su interés y valor literario, pero todas forman parte de nuestra proto historia del género.

En La Bestia del Apocalipsis, cuando su autor deja vagar su imaginación, consigue episodios vigorosos. Por decir lo imposible, si, conservando el mismo vigor imaginativo, hubiera escrito una novela laica, estariamos ante un notable logro fantástico del género cientificticio.

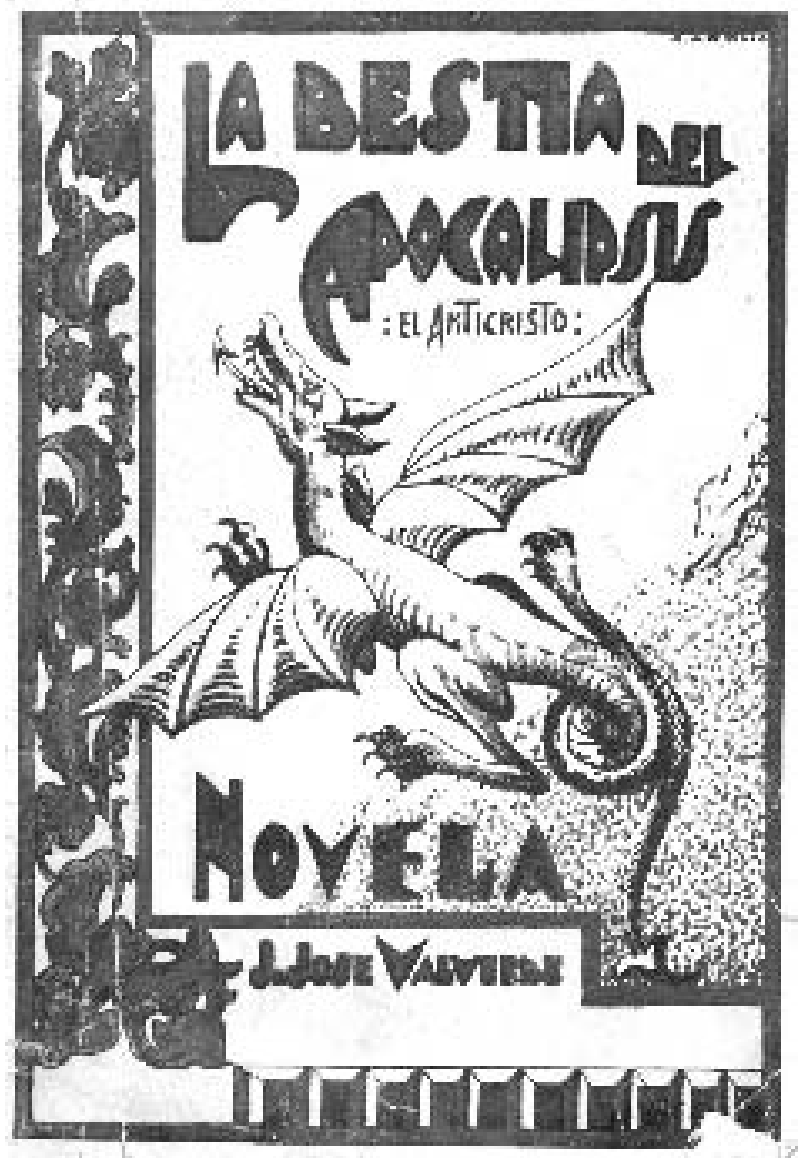

El fin de los tiempos es una novela que guarda cierta semejanza con la anterior, pues el desconocido Carlos Ortí y Muñoz se complace en hacer en ella una "interpretación conjetural" del Apocalipsis para mostrar cómo se están cumpliendo sus profecías. Es un autor del que sólo conozco este

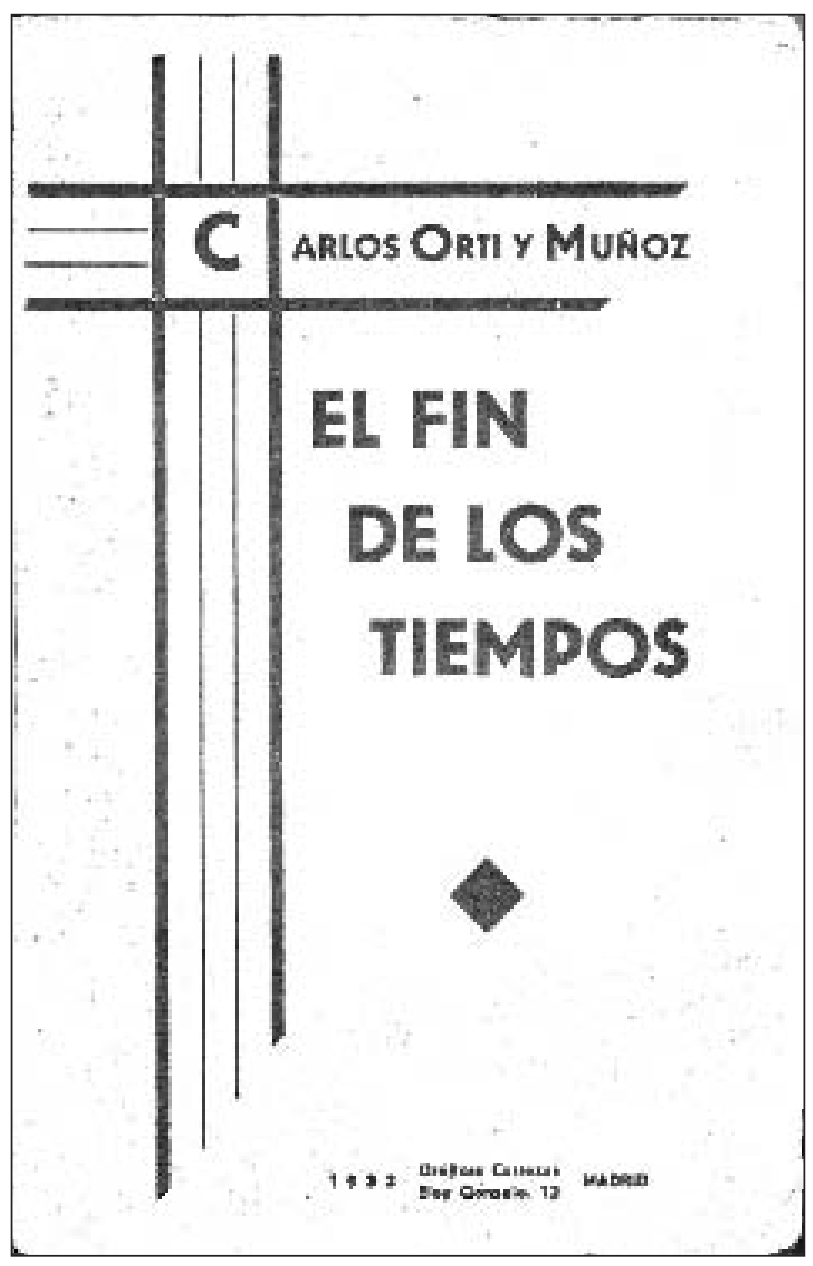

libro, que no figura en ningún manual de literatura y que pensé en principio que sería un sacerdote extremadamente conservador, hasta que lo encontré en el Padrón Municipal, en el que aparece como nacido en Córdoba el 7 de marzo de 1871, de profesión periodista cesante y residente en Madrid desde 1903, donde vivía en la calle de Santa Águeda n. ${ }^{\circ}$ 6, en cuyo tercer piso tenía una casa de huéspedes junto con dos hermanas. Falleció en el citado domicilio el 19 de diciembre de 1933. En la necrológica que le dedicó El Mundo Futuro, que lo califica de meritísimo escritor católico y autor de varias obras literarias, leo que era Licenciado en Filosofía y Letras y sobrino del catedrático de la Universidad Central D. Juan Manuel Ortí y Lara, que era de su misma ideología.

En un futuro indeterminado, quizá de cien o algunos más años 
la civilización ha seguido su impetuosa carrera, borrando con implacable saña cuanto se oponía a sus necesidades de amplitud y movilidad [...] y la humanidad ha progresado en todos los órdenes, lo mismo en la definición del concepto del Derecho que en la aplicación de la fuerza para torcerlo.

España, cuyo territorio comprende Portugal y Marruecos, completamente hispanizados, tiene doscientos millones de habitantes y es la potencia hegemónica del planeta, con enorme poderío militar: sus acorazados de 60.000 toneladas -es el ejemplo que pone- surcan los mares armados con cañones que pueden disparar a gran distancia proyectiles capaces de destruir ciudades enteras. Su régimen político sigue siendo la República que existía cuando se publicó la novela, con mayoría de izquierdas en el Parlamento, y su capital es la ciudad más populosa del mundo, un Madrid de cerca de veinte millones de almas. Cuenta con setecientas mil edificaciones que por un lado rebasan largamente las orillas del Manzanares y por el otro se acercan a la ribera del Jarama: hay muchos museos, bibliotecas y locales públicos de recreo, pero poco más de doscientas iglesias, ochenta católicas, cuarenta protestantes y cerca de cien de una nueva religión llegada del Kurdistán.

La acción arranca en la madrileña Puerta del Sol, convertida para entonces en una plaza cuadrada de cuatrocientos cincuenta metros de lado y flanqueada por edificios de treinta y cinco plantas, dotados de grandes ventanales por donde entran y salen los pequeños aeroplanos eléctricos que han sustituido a los automóviles, tanto de propiedad privada como de alquiler.

En su centro se levanta una construcción más chica, el Gran Café de la Luz, donde se prestan al cliente toda clase de servicios, desde los de restauración y espectáculos hasta los sexuales, lugar donde se fraguan todos los delitos, robos y crímenes que se cometen, pero frecuentado también por la alta sociedad.

Se comenta en el Café la noticia aparecida en los periódicos de que el Sol se acerca a una zona del espacio repleta de astros desconocidos que van a precipitarse sobre él y sus planetas, con el consiguiente riesgo para la Tierra.

Tres días después cruza el cielo un aerolito que se incendia y se fragmenta, colisionando sus restos con aviones y edificios, lo que produce muertos y heridos y da lugar a que, a la mañana siguiente, algunos de los que se acostaron ateos y republicanos amanezcan creyentes y monárquicos: para el autor coinciden el altar y el trono.

Cuando la Tierra llega a la zona de los aerolitos, la primera noche tiene lugar una espectacular Iluvia de estrellas que a todos admira, mas en la segunda caen sobre su superficie bólidos de gran tamaño ${ }^{7}$, uno de los cuales lo hace sobre los cuarteles de las afueras de la capital produciendo una gran mortandad.

La Tierra sobrepasa el espacio de los aerolitos y las gentes respiran aliviadas hasta que los observatorios astronómicos advierten de que un gran astro se dispone a penetrar en el sistema solar y puede chocar contra la Tierra, exigiéndose entonces a los gobiernos que hagan algo para impedirlo. Los periódicos presentan gran número de planes entre los que se impone el consistente en disponer a lo largo de la línea ecuatorial terrestre seis mil cañones de dieciséis metros de calibre que dispararán durante tres meses proyectiles de veinte toneladas a una velocidad de diez kilómetros por segundo, a fin de modificar el movimiento del planeta.

Por descabellado que pueda parecer, el plan se lleva a cabo, ya que las "multitudes ignaras" quedan seducidas por la propia inmensidad de las fuerzas puestas en juego, que el autor detalla en toneladámetros y de las que hago gracia al lector.

La civilización está tan científicamente adelantada que puede construir en un breve espacio de tiempo estas máquinas y estos obuses, así como los explosivos para impulsarlos, pero el autor no ofrece otro detalle de esta civilización que la proliferación de los aviones: raro es el particular mínimamente pudiente que no posee uno en su terraza. Por lo demás, no se mencionan siquiera ni el teléfono ni la fotografía, ya muy desarrollados en 1933. En cambio, entre los "milagros" que hacen los kurdos en sus templos figura la audición de música sin intérpretes ni instrumentos: mediado el siglo XXI, sólo ellos conocen el gramófono y los discos.

Otra cosa que nuestro escritor no parece imaginar son los cambios sociales a que tiene que dar lugar el paso de los tiempos, como tampoco el valor del dinero. Dos golfillos encuentran una moneda, pongo por caso, y comen un plato de judias y otro de chorizo por un real: a ese precio, con un euro podrían comer los dos cerca de un año.

ARBOR Vol. 187749 mayo-junio [2011] 627-638 ISSN: 0210-1963

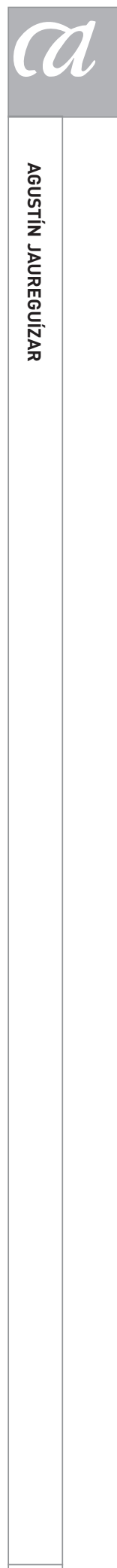

633 
Hay que decir que existen personas que esperan resignadas la muerte, por lo que dejan de trabajar, y el Gobierno español, por más que ateo, insta al Papa a que publique un Breve, como así hace, en el que diga a los católicos que el fin de la Humanidad todavia no ha llegado porque no se dan los presagios anunciados en el Apocalipsis ni es de prever una llegada inmediata de Cristo para juzgar a vivos y muertos: tampoco el Vaticano complace plenamente al buen Ortí.

Los gobiernos europeos contemplan con agrado la ocupación del África ecuatorial, compuesta por una serie de naciones que, lograda su independencia, exterminaron a la raza blanca y retornaron a la barbarie. Desean volver a convertirlas en colonias e instalar en ellas a los excesos de población que padecen. Los paises sudamericanos, por su parte, colaboran de grado, recelosos de una intervención de los Estados Unidos en su territorio.

Por fin llega el gran astro y se suceden ciento veinte horas de viva luz ininterrumpida y calor abrasador, tras las cuales, a causa de la tremenda evaporación, el cielo se cubre de espesas nubes y se padecen doscientas horas de noche. Las víctimas se cuentan por millones, más en el campo que en las ciudades, más en las naciones pobres que en las ricas, donde se ponen en marcha toda clase de recursos de supervivencia.

El astro sigue su camino sin llegar a chocar contra la Tierra, pero ésta se ve azotada por huracanes de violencia desconocida y por otras doscientas horas de lluvias torrenciales que provocan inundaciones devastadoras: el autor describe con verismo el horror de la situación, que es realmente pavorosa.

Cuando poco a poco se va restableciendo la normalidad, se comprueba que ha perecido cerca de la mitad de la especie humana y se ha perdido más de la mitad de su haber colectivo. La luna ha desaparecido, arrastrada por el gran astro, la velocidad de rotación de la Tierra se ha ralentizado, de modo que los días duran más, y su eje de rotación se ha desviado apreciablemente de su inclinación anterior, por lo que los cielos son distintos. Se trata de un declarado propósito del autor de hacer ver una vez más que se están cumpliendo las profecías que anuncia el Apocalipsis cuando se abre el sexto sello.

Se asiste a continuación al paso del astro cerca del sol, cuya atracción está a punto de capturarlo, mas da una vuelta en derredor de él y sigue rumbo a los espacios siderales ante el asombro de las multitudes que contemplan el espectáculo entre maravilladas y aterradas. Los planetas más cercanos al sol se precipitan sobre él levantando llamaradas gigantes y luego se constata que la órbita de la Tierra se ha vuelto mucho más excéntrica.

El calor es tan grande que las personas han de trabajar por la noche e intentar dormir por el día. Quienes disponen de aeroplano con chófer hacen que se remonten a las alturas y alli descansan al fresco. A los aviones, como a todas las demás máquinas, los mueve la electricidad, energía barata e inagotable porque se ha aprendido a tomarla directamente de la tierra.

A alguien se le ocurre entonces que sería una buena idea construir una ciudad aérea y así se hace en un plazo inverosímilmente corto. No es una ciudad puesta en órbita como cabría esperar -el autor no da para tanto-, sino una a modo de globo gigante que se estaciona a 4.000 metros de altura sobre Madrid. Su éxito es tal que se amortiza en su primer verano de explotación.

Curiosamente, está dominada por los kurdos adoradores del diablo que han importado su religión a Europa y que cada vez ganan más adeptos: sólo en Madrid suman ya ciento cincuenta mil. Es una religión tolerante con el sexo para cualquier mujer mayor de doce años. Sin embargo, lo más interesante de su doctrina es que permite el robo cuando el beneficio que obtiene el ladrón es superior al perjuicio que causa: eso los hace ricos.

Mas todo alcanza su fin. Cuando llega el duro y largo invierno, Villa Presidente Pérez Porras, que así se llama en honor del entonces presidente de la República, se queda desierta. El invierno es duro porque la temperatura en Madrid, por ejemplo, es la que antes correspondía a las frías estepas rusas; es largo porque en su nueva órbita excéntrica la Tierra recorre su afelio a mucha menos velocidad que su perihelio. Y no se mueve ni una ráfaga de aire para que se sigan cumpliendo las predicciones apocalípticas ${ }^{8}$.

Este invierno es causa de una gran hambruna que acaba con el veinte por ciento de la ya reducida población y son muchos los que emigran al África ecuatorial ocupada, cultivando aquellos suelos en busca de mejores condiciones de vida9. Ahora el Papa, y con él los católicos, están ya 
convencidos de que se acerca el fin de los tiempos. En clara referencia al Anticristo, dice el Pontífice a los cardenales:

¿No veis cómo el cielo es ya libro cerrado donde los caminantes no pueden leer su orientación? ¿No veis cómo los montes y las islas cambian de lugar ${ }^{10}$ arrollados por las turbulentas aguas? ¿No veis cómo en los países civilizados se levantan templos públicos para adorar al Ángel del Mal en contraposición al Dios del Sinaí?

El autor hace cuanto está en sus manos para dar cumplimiento a los anuncios apocalípticos y preparar su desenlace dentro de la más pura ortodoxia. El Papa nombra un Patriarca español para los territorios africanos a cuya designación y poderes universales de jurisdicción se oponen las potencias euroopeas, e Italia ocupa militarmente el Vaticano y recluye al Santo Padre en un convento hasta que devuelve al Patriarca a España y traslada la sede romana a África, volando con toda la curia en dos grandes aviones ${ }^{11}$.

La lectura se va haciendo progresivamente pesada y su acción no es demasiado coherente. El sol produce nubes de polvo que lo vuelven oscuro y la Tierra, al pasar cerca de él, recupera la luna que había perdido, ahora incandescente, para que se cumpla la postrera señal astronómica del Apocalipsis ${ }^{12}$.

Los sectarios kurdos encuentran un jefe, de nombre Mahometis, quien, convencido de que el padre Pedro, el Patriarca, es el hombre enviado por Dios para acabar con su religión, hace que sus seguidores en Madrid asalten el convento de carmelitas en que lo suponen alojado, torturando y matando a sus frailes y profanando sacrílegamente cuanto de sagrado se topan, sin que parezca producirse reacción ninguna de la autoridad.

Cuando descubren que vive en el chalé de un general prestigioso y cristianísimo, el que mandó las fuerzas españolas expedicionarias en África, igualmente lo asaltan, pero la prevenida familia, con el Patriarca a la cabeza, que fue antaño su capellán, y dos fieles criados se remonta por los aires en un maravilloso helicóptero que el militar ha diseñado y hecho construir.

El aparato es en realidad un avión, por supuesto de hélice, de despegue vertical, por más que el autor le diga heli- cóptero, que asciende a tal altura que sale de la atmósfera, primero, y escapa de la atracción terrestre, después, vagando por los espacios interplanetarios. La esposa y la hija del general pierden el conocimiento en el despegue y han de ser reanimadas con un frasco de sales. Otro detalle realista es que el ingenio está provisto de retrete.

Abandonada la órbita de la Tierra, el helicóptero se dirige con toda naturalidad a la de Marte y aterriza en su superficie, con una amplia exposición de cálculos astronómicos, algunos acertados. El autor explica en un post scriptum que ha querido mantenerse hasta aquí en una posición neutral a fin de que el lector poco religioso no abandonase la lectura del libro, pero que a partir de ahora manifestará con toda claridad su pensamiento. Lo primero no lo ha conseguido, ya que se le ve a ciegas el plumero, pero lo segundo lo va a lograr con creces.

El Patriarca puede celebrar cualquier sacramento en Marte, entre ellos dar la comunión y casar, que ya Ortí se ha cuidado de que se le concediese jurisdicción universal. Alli va a celebrar la primera misa alienígena de la historia sobre un altar de piedra que encuentran dispuesto, una misa cantada porque han llevado consigo un pequeño órgano y el sobrino del general es un más que aceptable chantre.

Aparecen entonces dos venerables ancianos vestidos de blanco y el de más edad entre ellos pronuncia con majestuosidad estas inefables palabras:

- ¿Eres tú, joh feliz mortal!, el viajero intrépido que ha conmovido los ámbitos del firmamento, conduciendo en sus manos a través de los espacios el Cuerpo real y verdadero de Jesucristo, Señor y Redentor nuestro, tantos siglos esperado, Pan de los Ángeles que ha de confortar nuestros espíritus para la lucha por la gloria de Dios?

Ni qué decir tiene que se trata de Elias y Enoch, ambos arrebatados al cielo en vida y frecuentes en las novelas de ovnis, que son los testigos del Apocalipsis en la tradición cristiana. Ellos han dispuesto el altar y los dos hacen su primera comunión, tras la cual firman como testigos el acta de matrimonio de la hija del general con su aristocrático ayudante y desaparecen. Durante la ceremonia se ve en el cielo a Mahometis intentando alcanzar Marte con la ayuda del diablo, pero el Ángel del Señor se lo impide a latigazos.

ARBOR Vol. 187749 mayo-junio [2011] 627-638 ISSN: 0210-1963

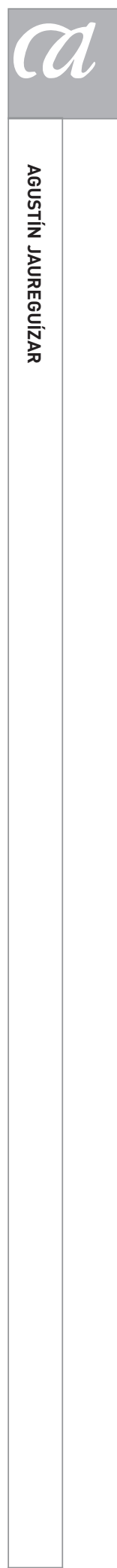

635 
Todo parece indicar que la Tierra va a perecer a los mil doscientos sesenta días que dice el Apocalipsis, tres años y medio de 360 días. El Patriarca sería entonces el regidor de la pequeña comunidad marciana -Pedro II es el nombre comúnmente aceptado para el último Papa- y Dios decidirá si estos supervivientes se extinguirán sin descendencia o si Mari y Enrique darán lugar a una nueva Humanidad.

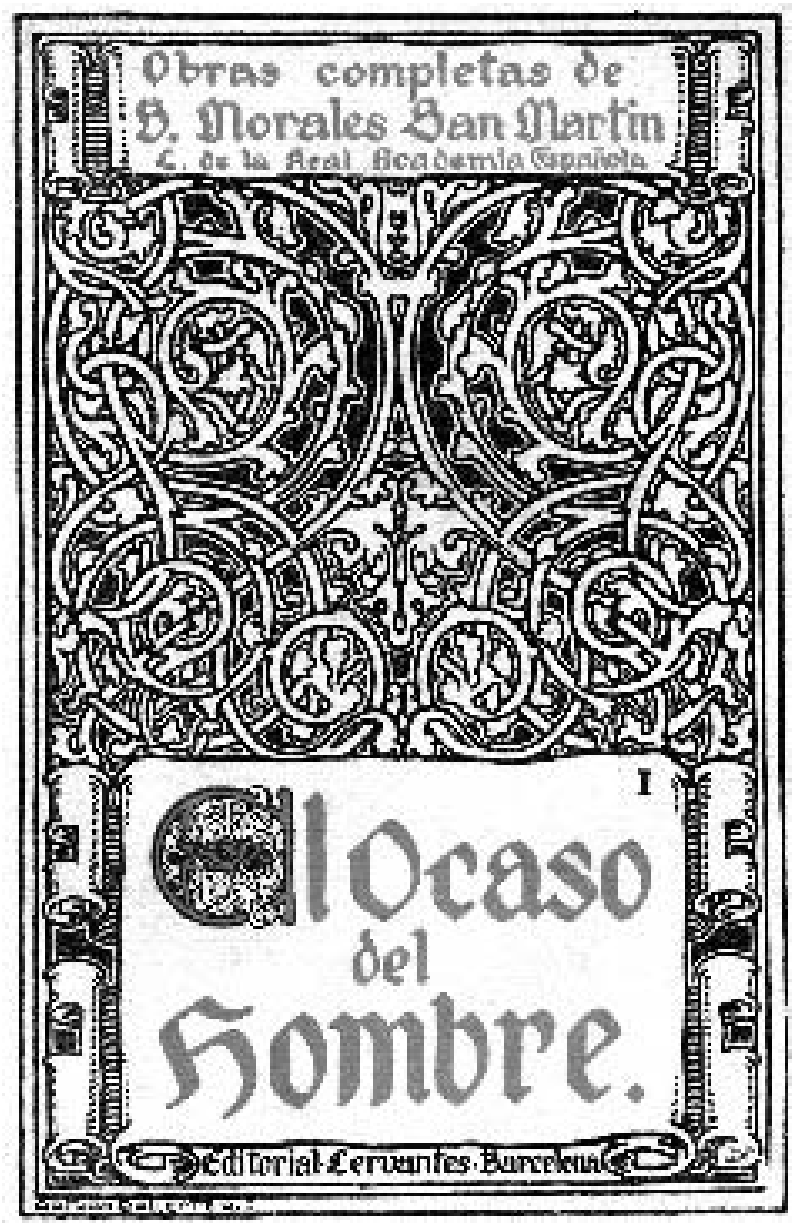

Asimismo poco conocida es la también conjetural El ocaso del hombre' ${ }^{13}$, por más que su autor, Morales San Martín, goce de cierta nombradía. Se ocupa igualmente del fin de la Humanidad, provocado por una guerra de exterminio convencional, pero espantosa, aunque su relación con la Biblia tiene más que ver con el Génesis que con el Apocalipsis. Bastaría el tono piadoso de su discurso para catalogarla entre las novelas religiosas pero, además, se concluye con la creación de una Humanidad más perfecta por parte de Dios.
La obra carece de la grandeza que, a su manera, poseen las anteriores, más La Bestia del Apocalipsis que El fin de los tiempos. De diferente desarrollo, más parece literatura de resignación que de escarmiento o advertencia. Está repleta de discursos morales y de acontecimientos que en ocasiones se cuentan en un lenguaje casi infantil, pero es todo un ejemplo de narración del fin de los tiempos, con una Humanidad absolutamente extinta: no podia faltar aquí.

Bernardo Morales San Martín nació en El Cabañal, Valencia, el 24 de abril de 1864. Fue novelista, dramaturgo, periodista y músico. Aficionado desde joven a las letras, relacionado con los hombres de la Renaixença literaria valenciana, aún encontró tiempo para estudiar leyes y farmacia. Influenciado por Blasco lbáñez escribió en casteIlano novelas de ambiente valenciano, como La Alcaldesa, La Rulla o Eva inmortal, fantástica como El ocaso del hombre. Escribió también teatro, generalmente trágico, y fue correspondiente de la Real Academia de la Lengua.

Se formó musicalmente en el Conservatorio de Valencia, ejerciendo la crítica musical y componiendo zarzuelas, piezas para piano y algunas canciones premiadas. Falleció en Valencia el 7 de enero de 1945. El Ayuntamiento de la ciudad ha dado su nombre a una calle.

\footnotetext{
... Y un mismo torpedo hundió al último dreadnought y al último submarino, y con ellos los restos maltrechos de todas las escuadras del mundo; el último aeroplano describió, como un bello morir, "el rizo de la muerte"; el último cañón estalló, rasgando la última bandera que ondeó al viento y aniquilando totalmente las últimas divisiones que aún se batían desesperadamente con la furia de la misma muerte... iy la última espada quedó rota al clavarse en el último corazón generoso que daba toda su sangre por el último ideal!

Al mismo tiempo que se convertían en polvo de las batallas todos los ejércitos del mar, de la tierra y del aire, en los pueblos y ciudades todas del mundo se cazaban los hombres entre sí como lobos hambrientos y canes rabiosos, revolviéndose proletarios y burgueses unos contra otros en una misma ansia de exterminio [...] El hombre llevó la guerra por la faz de la tierra y sobre el agua a pecho descubierto, como los héroes legendarios; pero aprendió de los reptiles, de las rapaces y de los monstruos marinos a llevar la guerra por las entrañas de la tierra, por el aire y por los senos de los mares... y la guerra última de los hombres fue un horror no conocido en el planeta ni en los mundos siderales.

¡Y la especie humana pereció!
} 
El ocaso del hombre está dividido en cuatro jornadas, de las que la primera, "El crepúsculo rojo", se inicia del tremendo modo que he reproducido. Mas la especie humana no ha perecido del todo. En una protegida tienda de campaña, en la que se reponía de sus heridas, ha sobrevivido el príncipe italiano Víctor Humberto. Piensa en quitarse la vida, pero una voz interior apocalíptica le dice "Camina, camina" y se pone en marcha.

Se encamina a una cumbre nevada en una de cuyas laderas encuentra a la joven princesa alemana Maria Victoria. En páginas un tanto farragosas ambos se enamoran, se desposan intercambiándose sus anillos y dan lugar a una nueva generación humana, con lo que se remata la primera jornada.

La segunda, "La Arcadia", arranca cerca de cien años después, con los príncipes centenarios. Sus descendientes se han agrupado en familias y el Anciano ve con creciente angustia cómo hay entre ellos abelitas y caínitas, que dicen que "esto es mío y no tuyo", cuando han sido educados en la ausencia de toda propiedad privada.

Descubren un día huesos de sus antepasados, restos de cerámica y armas, y averiguan así que no son lo que creían ser, los primeros hombres del mundo. Interrogan ansiosamente al Anciano y éste se ve obligado a responderles, iniciando su historia por el principio para proponerles un doble Génesis. Dios creó el sol y dos mundos que girasen en su torno, la Tierra y Venus.

Vencida la tentación, el hombre de Venus vivió en un Paraíso eterno. En la Tierra, en cambio, la serpiente tentó a la Mujer, ésta comió el fruto del árbol prohibido, dio de comer a su marido para ser como dioses y ambos fueron expulsados del Paraíso, repitiéndose la historia de Caín y Abel, el hermano contra el hermano como nacidos para la guerra. $Y$ dijo el Señor al Hombre: "Progresarás por tu amor desmedido a la guerra y formarás inconcebibles inventos mortíferos, con los cuales aniquilarás a la Humanidad y te extinguirás".

Y el Hombre construyó máquinas que surcaban las aguas del abismo y los senos de él y esparcian la muerte y causaban espanto a todos los seres. $Y$ forjó también otras máquinas que surcaban los aires y llevaban la destrucción y el terror en sus entrañas [...] Cuanto más sabios eran los hombres, con mayor odio y ferocidad se combatían y con mayor crueldad se exterminaban.
Mas el relato del Anciano no los convence. Los jóvenes más audaces salen un día de la Arcadia Feliz y se internan en el Valle de la Muerte. Regresan con la noticia de ciudades y palacios semienterrados y máquinas maravillosas y surgen de inmediato dos tendencias: la de quienes desean explotar los tesoros del viejo mundo y la de quienes prefieren seguir viviendo en sus cavernas, cultivando la tierra y pastoreando el ganado, que vuelven a ser cainitas y abelitas.

Los primeros invocan la Fuerza como sola Razón e inician la tercera jornada, "Lo tuyo y lo mío", que aceleradamente da paso al primer amor, el primer crimen, el primer creyente y el primer amo, de la manera que cabía esperar, para desembocar en la cuarta jornada, "El dios de la guerra". El hijo Caín adora al nuevo dios, mata a su hermano Abel y se proclama Rey del Mundo:

Todo fue inútil para la abnegada prole de Abel: el sacrificio de su libertad, la sumisión a la tiranía de Caín, el acatamiento a su capricho, su resignación ante todos los derechos feudales que el señor de vidas y haciendas impuso sobre la familia, la propiedad y la conciencia... Todas las concesiones hechas al dictador en aras del orden y de la paz fueron estériles.

El autarca se complace en todos los vicios, mujeres, riquezas y vidas, pues mata por puro placer, haciendo incluso sacrificios humanos por si mismo. Cuando al fin muere, sus hijos y capitanes se disputan su imperio en una repetida lucha que de nuevo acaba con la Humanidad, dejando otra vez solos al príncipe Víctor Humberto y la princesa María Victoria, ya más que centenarios, que terminan también por morir.

Extinguida la maravilla de la Creación, la Sabiduría ${ }^{14}$ propone a Dios en un epílogo que aún es pronto para que los ángeles pueblen la Tierra y que dé vida a un nuevo ser, no a partir del barro sino del polvo fosfórico de las estrellas, esencias de flores, ecos de brisas y miradas del Sol.

Así lo hace el Señor. Elimina todos los seres dañinos del mundo, destruye todos los venenos y parásitos, suprime los minerales tóxicos y arranca de cuajo el árbol tentador del Bien y del Mal y, eliminada la ponzoña terrena toda, forma al Hombre Perfecto que regirá su Obra.

ARBOR Vol. 187749 mayo-junio [2011] 627-638 ISSN: 0210-1963

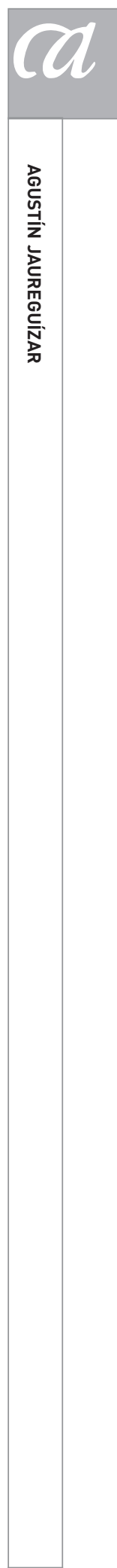

637 
1 Valverde, Juan José, La Bestia del Apocalipsis (El Anticristo), pról. de Francisco Arias Abad, Andújar, 1935, impr. "La Puritana" de Manuel Blanco Luque, rúst. int., $214 \mathrm{pp}$. en $8 .^{\circ}$ mlla. $(17,5 \times 12 \mathrm{~cm}),$.5 pta.

2 Del mismo modo que se hace en L'historioscope, de Mouton, aunque no parece probable que Valverde conociera la obra del francés. Lo he detallado en mi artículo sobre las protomáquinas del tiempo en la literatura fantástica española, incluido en La ciencia ficción española, Madrid, 2002, eds. Robel, y antes, en inglés, en The New York Rewiev of Science Fiction n. ${ }^{\circ}$ 130, junio 1999.

3 Delevi en latín es destruí. La $\mathrm{D}$ de quinientos con la $\mathrm{E}$ hace 600 , la $\mathrm{L}$ de 50 con la $E$ hace 60 , y la $V$ de cinco con la I hace 6: en total 666 que, según el Apocalipsis, es el conocido número de la Bestia.

4 Una extendida tradición cristiana sostenía que Elías y Enoch serían los dos testigos anunciados en el Apocalipsis para, al final de los tiempos, combatir con su predicación a la Bestia que surgiria del Abismo, siendo muertos por ella pero resucitando a los tres dias y medio para subir al cielo ante los ojos espantados de sus enemigos.

5 Como pueden ser las españolas que a continuación comento y las inglesas El amo del mundo de Robert Hugh Benson y la Trilogía del Dr. Ransom de C.S. Lewis.

6 Ortí y Muñoz, Carlos. El fin de los tiempos, Madrid, 1933, Gráficas

Recibido: 1 de diciembre de 2010 Aceptado: 3 de enero de 2011 España (San Roque 4) en portada, Gráficas Carrozas (Eloy Gonzalo 12) en cubierta, exclusiva para la venta Sindicato Exportador del Libro Español, rúst., int., 268 pp. en $8 .^{\circ}$ mayor (22x14 cm.), 6 pta.

7 "Y las estrellas del cielo cayeron sobre la Tierra, como la higuera suelta sus higos verdes al ser sacudida por un viento fuerte" (Ap. 6, 13).

8 "Después de esto, vi cuatro ángeles de pie en los cuatro extremos de la Tierra, que sujetaban los cuatro vientos de la Tierra para que no soplara el viento, ni sobre la Tierra ni sobre el mar ni sobre ningún árbol" ( $A p$. 7, 1).

9 "Y la mujer huyó al desierto, donde tiene un lugar preparado por Dios para ser alimentada mil doscientos sesenta dias" (Ap. 12, 6).

10 "Y el cielo fue retirado como un libro que se enrolla, y todos los montes y las islas fueron removidos de sus asientos" (Ap. 6, 14).

11 "Pero se le dieron a la Mujer las dos alas del águila grande para volar al desierto, a su lugar, lejos del Dragón, donde tiene que ser alimentada un tiempo..." (Ap. 12, 14).

12 "Y segui viendo. Cuando abrió el sexto sello, se produjo un violento terremoto, y el sol se puso negro como un paño de crin, y la luna toda como sangre" (Ap 6, 12).

13 Morales San Martín, Bernardo. El ocaso del hombre, Barcelona, 1920, Editorial Cervantes (Rambla de Cataluña 72), impr. Valencia, talleres tipográficos La Gutenberg, rúst., int., 339 pp. en $8 .^{\circ}(19 \times 13 \mathrm{~cm}$.), 4 pta.

14 Sabido es que la Sabiduría o la Palabra -debar Yahweh- acompañó a Dios en la obra de Creación, según el Génesis. 